\title{
The emergence of social assistance in China
}

Joe C. B. Leung

Department of Social Work and Social Administration, University of Hong Kong

Running title: Emergence of social assistance in China

Key words: social assistance, unemployment, urban poverty, laid-off employees, social protection

Accepted for publication January 10, 2006

Correspondence to:

Joe C. B. Leung

Department of Social Work and Social Administration

The University of Hong Kong

Pokfulam Road, Hong Kong

Tel: (852) 28592085

Fax: (852) 28587604

E-mail: joe-leung@hku.hk 


\begin{abstract}
The phenomenal success of China's market-oriented economic reform since the 1980s has rendered the traditional employment-based social security system increasingly inadequate and inefficient. Based on the re-structuring of the social insurance programmes, welfare reforms have left an increasing number of people outside the emerging social protection system. Mounting unemployment and urban poverty are threatening social stability, which calls for prompt and effective government intervention. Against this background, the development of a residual social assistance programme has become paramount. This article outlines the development of the China's social assistance programme, including its design, implementation and trends. The Chinese government has given high priority to the establishment and institutionalisation of this programme. To have an effective social assistance programme in the context of an increasingly pluralistic society, China is facing the profoundly challenging task of designing a coherent and over-arching social protection system that would cover retirement, medical care, unemployment, and poverty alleviation.
\end{abstract}




\section{Introduction}

As an integral part of the social protection system, social assistance programmes in different countries may embrace a wide range of services in kind and in cash. Primarily, social assistance is a means-tested scheme where eligibility is dependent on the test of income (Gough, Bradshaw, Ditch, Eardley \& Whiteford, 1997). Financed mainly by public funds, social assistance programmes have received growing attention from governments and social policy analysts in recent years in developed welfare states (Ditch, 1999; Ditch, Bradshaw, Clasen, Huby \& Moodie, 1997; Ditch \& Oldfields, 1999; Eardley, Bradshaw, Ditch, Gough \& Whiteford., 1996ab; Mackay, 2001; OECD, 1998ab, 1999; Sainsbury, 1996; Saraceno, 2002), in developing countries (Lustig \& Inter-American Development Bank, 2001; Subbarao et al., 1997; Wilson, Kanji \& Braathen, 2001) and in transition countries (Braithwaite, Grootaert \& Milanović, 2000; Hutton \& Redmond, 2000; Mikhalev, 2001; Milanović, 1998). The 1997 Asian financial crisis underscored the need for more institutionalised social assistance policies and programmes for people facing the risk of unemployment and poverty (Oritz, 2000, 2002). Facing escalating demands, most social assistance programmes have to be re-structured to target those in need, to improve efficiency, contain rising costs and promote work requirements.

China has enjoyed almost uninterrupted economic growth at an average rate of 9 per cent a year since the initiation of the market reforms in the 1980s, and the country is expected to maintain an annual growth rate of 7-8 per cent in the coming decade (9.1 per cent in 2003) (The Economist, 20 March, 2004). The phenomenal success of China's market-oriented economic reforms has been accompanied by a wide array of social problems. Economic reforms in state-owned enterprises (SOEs) have rendered the traditional work unit-based social security system increasingly inadequate and inefficient. For two decades, the Chinese government has been trying to develop a more pluralistic, independent, effective and affordable social security system that will be compatible with both a thriving market economy and a flagging socialist 
political structure. Social security reform centres on the establishment of partially funded systems in retirement, unemployment and medical insurance that move away from the current pay-as-you-go systems, and the development of a basic social assistance programme covering all urban residents (Leung, 2003). Indeed, an effective social security system would not only facilitate economic reforms by promoting productivity, but also enhance social harmony through the mitigation of social tensions and conflicts (Information Office, State Council, April 2002, September 2004).

In his annual government report to the National People’s Congress in 2002, the former Chinese Premier Zhu Rongji, for the first time in history, used the term 'vulnerable populations' to refer to those disadvantaged groups outside the traditional employment-based social protection system. They include the unemployed, rural migrants working in the cities and low-income families (Zheng, 2003). New Chinese leaders continued to reiterate the government's commitment to help the poor and reduce regional disparities (People's Daily, 26 May 2004). Facing the problem of mounting unemployment and the inadequacy of the contributory social insurance programmes in both coverage and income protection, the Chinese government has, since the late 1990s, put greater emphasis on the development and institutionalisation of the means-tested social assistance programme. This programme has grown dramatically in recent years in terms of expenditures and the number of recipients. In moving towards a socialist market economy, the programme acts as a 'safety net' for the urban poverty-stricken residents and a 'shock absorber' mitigating social tensions resulting from market-oriented reforms. Under the government pledges of the 'two guarantees' and 'three social protection lines', the social assistance programme has emerged as the foremost component of the Chinese social protection system, independent from the work units. ${ }^{1}$

\footnotetext{
${ }^{1}$ The 'two guarantees' refer to payments of living allowances to laid-off employees and pensions to retirees. 'The three social protection lines' refer to three programmes, namely social assistance, unemployment insurance and living allowance for laid-off employees.
} 
This article presents the background and the development of the social assistance programme, including the design, implementation and recipient profile. The shortcomings and achievements of the programme are appraised. Towards the end of the article, the implications of the programme to the establishment of a more coherent social welfare system in China are explored.

\section{Rising unemployment and poverty}

Immediately after 1949, the Chinese government provided a mixture of assistance including cash assistance, mutual help through material and money donations, promotion of neighbourhood-based economic production groups and reduction of taxes to assist the unemployed and poverty-stricken. Under the centrally-planned economy modelled on that of the Soviet Union, the system of public ownership, full and life-long employment, job creation and assignment, and restricted labour mobility was regarded as a superior feature of socialism. Since social security was employment-centred, each work unit functioned as a self-sufficient ‘welfare society' within which an individual received employment and income protection, and enjoyed heavily subsidised benefits and services such as housing, food and education (Leung, 1994; Leung, 2003; Leung \& Nann, 1995; Walder, 1986). Under the socialist system, the role of the government in welfare was limited to providing support for the 'three nos' - those with no families, no working ability and no source of income. These included mainly childless frail older persons, the disabled homeless and orphans. The size of this population was small, and the problem of urban poverty was therefore limited. As a very egalitarian society, the Gini Coefficient in cities in 1978 was only 0.19 (Khan \& Riskin, 2001).

From the start of the 1980s, the 'iron rice bowl' began to be regarded as impeding economic efficiency, labour mobility and productivity by acting as a disincentive. The government was aware that a re-structuring of the social security system would be an 
indispensable part of the whole process of market-oriented economic reform. ${ }^{2}$ With the emergence of a more pluralistic economy and employment structure after the economic reforms, more urban employees have been left outside the traditional social security network provided by the SOEs. In 2003, only 26.8 per cent of urban employees worked in SOEs, compared with 76.2 per cent in 1980 (China Internet Information Centre, 2004).

By the end of 2003, the official urban unemployment rate was 4.3 per cent, representing eight million people. But Chinese economists estimated that the actual rate was double or triple the official rate (China Daily, 23 December 2003). ${ }^{3}$ From 1998 to 2003, the accumulative total number of employees laid off from SOEs was 28.18 million (six million layoffs in 2003). The laid-off employees were mainly around 40-50 years old, poorly educated and low skilled, and constituted a high proportion of female employees. Their opportunity for re-employment is dim. In addition, there are around 10 million new entrants into the job market each year, while the number of jobs created each year is only around nine million. The situation is further aggravated by the 100 million surplus workers in the rural areas intending to move into cities for jobs (Hussain, 2003; Mo, 2004; Ministry of Labour and Social Security, 2004; Information Office, State Council, April 2004). Even with high economic growth rates, the unemployment

\footnotetext{
2 Economic reforms focused on the gradual liberalisation of the economic structure and increases in the production and management autonomy of SOEs. The introduction of the taxation system provided an incentive for SOEs to make profits and enhance efficiency. In terms of employment, steps were also taken to erode the traditional socialist commitment of life-long employment or job security through the introduction in 1986 of contract work, dismissal procedures, bankruptcy law and unemployment insurance. The traditional job assignment system was gradually replaced by the use of the labour market by both employers and job-seekers. As a result, workers became liable to become unemployed as a result of dismissal, bankruptcy or termination of contract. In addition, the egalitarian wage system was dismantled to provide incentives for improved performance (Leung, 1994; Leung, 2003).

${ }^{3}$ In China, the unemployed population includes only those who have urban household registration, are within working age and register at local employment offices for jobs. The laid-off employees are not regarded officially as unemployed because they can still maintain employment relationships with their employers, and can receive living allowances and social security benefits from them.
} 
situation in China remains bleak.

In the early 1990s, laid-off employees were allowed to receive living allowances and social security benefits from their employers. Since 1995, re-employment service centres had been set up to provide basic living allowances, re-training, payment of social security contributions and job referrals. ${ }^{4}$ Laid-off employees could stay at the centres for a maximum of three years. However, the re-employment rate of these laid-off employees within a year's time had been declining from over 50 per cent in 1998 to 31 per cent in 2001 (Ru, Lu \& Li, 2003: 6). Even with government re-assurance, a small proportion of the laid-off employees could not receive their entitled allowances and support. In 2001, the government announced the gradual closure of these centres. Thereafter, new laid-off employees would have to terminate their employment relationship with their work units immediately and seek assistance directly from the unemployment insurance or the social assistance programmes.

The unemployment insurance schemes set up in 1986 were under-utilised in the late 1980s, largely because of the restricted eligibility and narrow coverage. As unemployment rates rose in the early 1990s, the programme became a more prominent means of providing assistance to the unemployed. Yet with a relatively low contribution rate (3 per cent of the total wage), the fund evidently cannot cope with the demand from rising unemployment. Those receiving assistance from the programme are mainly workers whose contracts have been terminated and laid-off employees who have spent three years in the re-employment service centres but still cannot find a job. The programme offers a basic living allowance to the unemployed for a maximum period of two years, depending on the length of service. According to the regulations, the benefit level should lie between 120 and 150 per cent of the local poverty line, but in some places it is actually 70-80 per cent of the local minimum wage (Leung, 2003). In this sense, it is a form of

\footnotetext{
${ }^{4}$ Re-employment service centres were operated by the local governments and financed by contributions from SOEs, unemployment insurance funds and government allocations (Leung, 2003).
} 
non-means-tested and flat-rated unemployment assistance. In 2003, around 40 per cent of urban employees had participated in the unemployment insurance schemes, constituting a total of 4.15 million benefit recipients (Mo, 2004).

Not only are unemployment insurance benefits lower than the laid-off allowances, but by changing their status from that of laid-off employees to that of unemployed persons, employees will lose their employment-based social security protection, notably their pensions, medical care and housing benefits (China Daily, 21 December 2004). Taken together, a laid-off employee can, in theory, receive unemployment benefit support for a total duration of five years (three years from the re-employment service centre and two years from the unemployment insurance programme). These rather generous provisions reflect the government's concern to provide sufficient support to employees laid off from SOEs.

The pension system in China is riddled with problems of inadequate funds and narrow coverage. Facing a rapidly ageing society, the number of retirees in urban areas will rise from 48 million in 2004 to 70 million in 2010, and then further to 100 million in 2020. To ensure that retirees can receive their benefits promptly, the central government has to subsidise heavily those pension funds, managed by local governments (Sin, 2005). In 2003, statistics showed that only 45 per cent of urban employees had participated in the retirement insurance programmes (China Internet Information Centre, 2004). A nationwide survey in 2000 covering 10,171 older urban residents showed that 27 per cent of them were not entitled to pensions. Specifically, some 44 per cent of older women and 51 per cent of older people aged over 80 did not have pensions. In other words, they have to rely mainly on family support to make ends meet. Even among those with pensions, 40 per cent expressed worries about the insufficiency of their pension benefits (China Research Centre on Ageing, 2002: 2). Reforms of the medical insurance programme, together with the rising costs of medical care, mean rising fee payments (Bloom \& Tang, 2004; China Daily, 17 January 2005). According to a report from the State 
Council's Development Research Centre in 2005, the medical care system and reforms have turned medical services into the exclusive privilege of the rich. Some 45 per cent of urban residents were not covered by medical insurance programmes (China Network, 2005).

With market-oriented reforms in social services, urban residents have to shoulder higher expenses on retirement, education, medical care and housing services. With the system of job guarantee and the rationing of basic commodities disbanded in the cities, the problem of urban poverty has become more critical. Estimates of the size of the urban poor range from 12 million to 30 million (Guan, 2003; Tang, sha \& Ren, 2003; Zheng, 2003). Estimates by the State Statistical Bureau, adopting a poverty line of annual per capita income of 1,875 yuan (US\$1 = 8.08 yuan) in 2000, suggested that 10.5 million people, or 3.1 per cent of the urban population, were poverty-stricken (Asian Development Bank, May 2004: 4). In contrast to impressive poverty alleviation efforts to reduce the poverty population in the rural areas, urban poverty has become more prominent since the 1990s (Asian Development Bank, May 2004; World Bank, 2004). Unlike in the rural areas, however, the Chinese government has not yet established a national poverty line and the actual size of urban poverty remains contested.

\section{The emergence of the urban-based social assistance programme}

Article 45 of the Chinese Constitution recognises the right of the Chinese people to state assistance to maintain their basic standard of living. However, for decades, China operated only a limited relief programme in the cities, catering mainly for disabled veterans and the 'three nos'. Many of the 'three nos' would be received into institutional care, such as homes for the aged and orphanages. In addition, the programme also catered for 'special targets', including redundant workers forced to take early retirement during the period of economic adjustment in the early 1960s, victims of political movements, discharged war criminals and old overseas Chinese living in China. In 1992, only 190,000 people (0.06 per cent of the urban population) in 
the whole country received assistance, involving a total of 87.4 million yuan, and the per capita benefit was only 38 yuan per month (Tang et al., 2003).

To re-structure the traditional social assistance programme, the Shanghai government extended the coverage, raised the level of benefits and secured financial commitments to the programme in 1993. Based on the Shanghai experiences, the Ministry of Civil Affairs encouraged other cities in 1994 to adopt the programme. The number of cities that adopted the reformed programme increased to 12 in 1995, 116 in 1996, 334 in 1997 and finally covered all 668 cities in 1999.

Known as the ‘Minimum Living Standard Guarantee System’ (MLSGS), the means-tested programme provides assistance to persons with urban household registration status (around 40 per cent of the national population). Based on a budget-standard approach, the assistance line is calculated according to the minimum standard of living, often based on expenditure surveys of low-income households and the financial capacity of the local authority. What a household finally receives is the difference between the total benefits eligible (local assistance line times the number of persons eligible within the household) and the total household incomes.

At a subsistence level, the assistance would merely cover basic food and clothing costs, and would not take into account rental and medical care (Leung \& Wong, 1999). The central government issued general guidelines for determining the assistance line at the basic-need level. In effect, the assistance lines set up by local governments varied across cities. In principle, the assistance line should be below the minimum wage, pensions and unemployment benefits. For example, in Beijing the minimum wage per month in 2003 was 490 yuan, unemployment insurance benefits were 329-419 yuan, minimum pension benefits were 466 yuan and the MLSGS was 290 yuan (Beijing Labour and Social Security Bureau, 2004).

In 2003, the average national assistance level was 160 yuan per person per month. The assistance levels are 200-300 yuan for large coastal cities, 150 yuan for most provincial capitals 
and 100 yuan for county-level cities (Tang, 2004). ${ }^{5}$ As such, the highest assistance lines can be two to three times greater than the lowest. The discrepancies indicate more the differences in the financial capacity of the local governments than differences in the living standards between cities. The assistance lines are subject to annual adjustments. From 1993 to 2000, the assistance standard of the MLSGS in Shanghai was adjusted nine times, increasing from 120 yuan to 290 yuan (Shanghai Civil Affairs Bureau, 2004a). Instead of reflecting the changes of consumer prices, the adjustments really showed that the assistance line had been started at a very low level. On average, the national assistance level in 2003 was only 14 per cent of the average wage and 23 per cent of the per capita disposable income of urban residents.

In 2003, the average benefit actually received by a recipient per month was only 55 yuan. As expected, the highest payments were found in coastal cities and provinces, such as Beijing (231 yuan), Shanghai (138 yuan) and Zhejiang province (113 yuan), and the lowest were in the central provinces of Hebei (36 yuan), Wunan (42 yuan) and Henan (43 yuan) (Ministry of Civil Affairs, 2004a). Even under the same city administration, there would be geographical variations in assistance standards. For example, the assistance levels in Shanghai in 2003 were 290 yuan in urban districts and 150-183 yuan in rural areas. In practice, the standard can be adjusted, with a 20 per cent increase for older persons living alone and a 30 per cent increase for the severely disabled. According to Shanghai’s regulations, assistance will be withdrawn gradually within a period of two to six months after the recipients have obtained employment or received an increase in their incomes (Shanghai Civil Affairs Bureau, 2004ab).

The 1997 circular issued by the State Council defined the three types of targets covered by the programme to include the traditional 'three nos'; the unemployed whose unemployment insurance benefits have been terminated with their total household incomes below the locally

\footnotetext{
${ }^{5}$ At the high end of the provincial cities are Guangzhou (300 yuan), Beijing (290 yuan), Shanghai (290 yuan) and Shenzhen (290-344 yuan). At the lower end are Nanchang (143 yuan), Xining (155 yuan) and Guiyang (156 yuan).
} 
defined assistance line; and those employees whose working incomes, including pensions and allowances, are below the locally defined assistance line (Tang et al., 2003). In the initial years, if the applicant or any of his or her family members were an employee of an SOE, then the SOE should be responsible for paying the benefits to the eligible applicant. The MLSGS, managed by the local civil affairs departments, served only persons who had no SOE connections, including those working in bankrupted SOEs. The policy was described as 'one should take care of one’s own baby'.

To facilitate the development of the programme, each city government has to set up a cross-departmental leading group to formulate operational policy and guidelines. Being community-based in operation, each applicant has to make his or her application to the local residents' committee. A residents' committee is a neighbourhood-based mass organisation, supervised by the street office, the agency of the district People’s Government. ${ }^{6}$ An applicant has to show all the relevant documents, including household registration card, income receipts and household bills. ${ }^{7}$ The cadres of the residents' committee would carry out the investigations, and make recommendations to the street office and then the district civil affairs bureau for approval. After approval, the residents' committee would be responsible for the delivery of benefits, the keeping of records and reviewing the situation of recipients periodically. In such a way, the administrative costs of setting up and operating the programme can be kept to a minimum.

\footnotetext{
${ }^{6}$ As an extension of the district people's government, a street office is in charge of the delivery of local public and social services, such as family planning, sanitation, social welfare, public health, public security and environmental management. On average, it administers a population of around 50,000 residents. Residents' committees comprise members elected by local residents. As elected residents' representatives, they would become government cadres and have to assist the street office to deliver public and social services (Leung, 2000). ${ }^{7}$ An applicant, irrespective of where he or she lives, should apply to the residents' committee of the street office where his or her household registration belongs, and receives the benefits from that street office accordingly. In general, the MLSGS is portable, and a recipient can still receive benefits even though he or she has moved to another district under the same city administration.
} 
According to the regulations, only urban residents with local non-agricultural household registration status within an applicant's household are to be included in the assessment. Spouses from the rural areas or from other provinces without local household registration status would not be counted in calculating the benefits. Yet monetary incomes from all family members living together are included. One of the major problems facing neighbourhood cadres is assessing the actual incomes of applicants. Documents indicating incomes are easily subject to fraud, and hidden incomes from informal employment are widespread. Therefore, it was a common practice in some cities to use the local minimum wage as the income of an able-bodied person. Similarly, applicants would be assumed to have those eligible incomes, such as a pension and unemployment benefits, rather than what they actually earn (Hong \& Wang, 2001; Tang et al., 2003). In 2002, the government pledged to eliminate the practice of using 'assumed incomes' for determining the incomes of applicants.

In principle, there is no limit to how long a person can receive social assistance benefits. One can theoretically receive the benefits as long as one needs to. In practice, however, only persons who are unable to work are provided with long-term assistance. Others are provided only with short-term benefits subject to regular review for continuation. Those who are able to work must register at employment agencies for jobs and retraining. They cannot reject job offers. Failure to do so will lead to their benefits being terminated. The unemployed have to participate in voluntary community work, ranging from 10 to 40 hours per month. Extension of assistance is conditional on the satisfactory participation in community work (Ministry of Civil Affairs, 1999; Li, 2004).

At the level of the street office, there is a MLSGS committee comprising party secretary, police, neighbourhood cadres and residents' representatives to process applications, review cases and supervise community service placements. To facilitate 'public monitoring' of the 
situation of recipients, the names of the recipients and the amount of benefits received are made public on neighbourhood bulletin boards on three occasions: during the initial application, at the initial assessment, and during the final approval periods. Cadres can also interview neighbours to collect information on the living standards and life style of the applicants. Life styles that include such things as eating in restaurants, wearing jewellery, owning of pets and having mobile phones are considered unacceptable (Tang, 2004). In some cities, families who have violated the one-child policy regulations are not eligible (Guangzhou People’s Government, 2004). To the West, this practice violates individual rights. But to the Chinese government, it is a necessary means of preventing fraud, so that assistance is given only to the deserving poor.

In financing the programme, the initial arrangement before 1999 was for the local governments to cover all expenses. In practice, there were different patterns of cost-sharing between the city and district governments. Yet with the budget constraints of local governments, the size of beneficiaries and the level of assistance were largely dependent on the financial capacity and commitment of the provincial and city governments to support the programmes (Tang et al., 2003; Yu, 2002). The crux of the problem is how to ensure that local governments can cover the mounting expenditures.

To supplement the MLSGS, specific supplementary benefits have been developed in rich cities such as Shanghai, Beijing and Guangzhou. To cope with the problem of high inflation in the early 1990s, Shanghai introduced the food-stamp programme in 1994. Low-income families and MLSGS recipients were able to obtain free grain, edible oil and sugar from designated stores. In-kind assistance comprised two types of schemes. The 'Blue Card' Scheme provided supplementary assistance (around 40 yuan per month) to persons already receiving the MLSGS, while the 'Green Card' Scheme (around 30 yuan per month) provided assistance to low-income families whose incomes were slightly above the MLSGS standards. The two 
'cards' were combined together in 1999, and food rationing was replaced by cash assistance. In 2003, a total of 130,000 people, of the 0.45 million MLSGS recipients (4.5 per cent of the population), received the benefits (Shanghai Civil Affairs Bureau, 2004a).

In Shanghai, limited and means-tested medical aid (a maximum of 5,000 yuan a year), educational aid (tuition exemption or reduction and scholarships for excellent students) and housing aid (low cost public housing units and rental assistance) were provided. But educational and housing aids were managed by separate government authorities. The coverage of these programmes is limited. In 2003, 58,200 hospitalisation payments were made, with an average of 1,089 yuan for each payment (Shanghai Civil Affairs Bureau, 2004a). In Beijing, among the 120,000 MLSGS recipients in 2002, only 4,000 people received medical assistance (Li, 2004).

Lastly, local charity bodies and trade unions, mobilised by the government, provide cash or in-kind assistance in education, medical service, food and training to recipients of the MLSGS. But the development of NGOs as charity businesses is still rudimentary and government-led.

\section{Phenomenal expansion of the programme}

In 1999, the government had pledged to further expand the MLSGS for three major reasons. First, the problem of laid-off employees had become critical. The government issued a policy directive to strengthen the 'three social protection lines', namely the allowances for the laid-off employees, unemployment insurance and the MLSGS. The MLSGS can provide a safety net as a last resort for the unemployed who are not entitled to unemployment assistance or whose unemployment assistance has expired. In 1999, it was estimated that about 10 per cent of those eligible for laid-off assistance did not receive their entitled allowances (Leung, 2003). Likewise, because of the inability to make contributions by loss-making SOEs, some pensioners were 
unable to receive their payments. Meanwhile, the government is determined to abolish the policy of 'one should take care of one's own baby'. Local governments are to assume full responsibility for providing financial assistance to needy state employees.

Second, to celebrate the 50th anniversary of the People's Republic of China in 1999, the benefit levels of unemployment insurance, the MLSGS and laid-off allowances were raised by 30 per cent (Tang et al., 2003). With the raising of the assistance line, more people became eligible for assistance, so expenditures on the programmes inevitably escalated. The central government provided local governments with 400 million yuan to cover 80 per cent of the increased expenditures. Seven economically prosperous coastal provinces had to cover the increases themselves (Tang et al., 2003).

Third, even though the number of recipients had reached over four million by 1999, estimates based on the local assistance lines showed that the number of people eligible for assistance in reality had reached 14.8 million. Therefore, the programme caters to only about 27 per cent of the poverty-stricken population. Not surprisingly, the economically well-off cities and provinces could cover basically all the persons eligible for assistance. Western and central provinces still had a large proportion of eligible people who were not covered (Tang et al., 2003). The low coverage was mainly attributed to the widespread shortage of funds among local governments.

Against this background, the central government put pressure on local government to extend the coverage. As a result, the number of recipients jumped from four million in 2000 to 11.7 million in 2001, and further to 20.7 million in 2002. The phenomenal increases in the number of recipients indicated that the central government was determined to extend the programme to cover all those who are eligible. By the end of 2003, the total number of recipients reached 22.47 million, representing 4.2 per cent of the urban population, as compared with only 1.4 per cent in 2000 (Ministry of Civil Affairs, 2004a). 
Understanding the uneven development and the financial difficulties of local governments, the Chinese government readily assumed the responsibility to provide funding support to this programme to extend the coverage and to ensure that those who are eligible should receive assistance. Thereafter, the financial commitment from the central government soared substantially from only 0.4 billion yuan in 1999 (26 per cent of the total expenditures) to 9.2 billion yuan (61 per cent of the total expenditures) in 2003. (Table 1) Seven more prosperous provinces and metropolises, including Guangdong, Jiangsu and Zhejiang, Shanghai and Beijing, do not receive any subsidies from central government. The proportion of subsidies varies significantly from 16 per cent for Fujian Province in the coastal area to over 70 per cent in Gansu and Guizhou Provinces in the west. Also, contributions from different levels of government, namely the provincial, city and county levels, vary as they lack a standardised formula. In principle, subsidies from the central government are to take into consideration the total number of recipients and the financial capacity of the local governments. In terms of the absolute amount, provinces in the rusty industrial belt in northeastern China, namely Liaoning, Heilongjiang and Jilin, received the largest central government subsidies. Altogether, these three provinces had over 4.6 million MLSGS recipients in 2003 (Ministry of Civil Affairs, 2004a). Indeed, these provinces have the highest concentration of loss-making national SOEs.

With rising contribution from the central government, the absolute amount of contribution from the provincial and city governments has declined from 6.26 billion yuan in 2002 to 5.9 billion yuan in 2003 (Table 1). Using Sichuan Province as an example, the proportions of contribution from central, provincial and city governments were 30.8 per cent, 5.8 per cent and 63.3 per cent, respectively, in 1999. As the expenditures increased sixfold from 1999 to 2002, the percentages changed to 62.8 per cent, 9.9 per cent and 27.3 per cent, respectively, in 2002 (Ji, 2002).

\section{Table 1 in about here}


Overall, the dramatic increases in the number of recipients and expenditure in the early 2000s were due to continuous massive layoffs from SOEs, gradual closure of re-employment centres, the abolishment of the policy of 'one should take care of one’s own baby', the use of actual incomes in eligibility assessment and subsidies from the central government. Even with increasing support from the central government, the demands on local governments, particularly central provinces, to finance the programmes are still heavy. With an increased number of recipients, the management structure and staffing of the programme at the community level have been over-stretched.

\section{Profile of recipients}

With mounting subsidies, the central government found that it was necessary to have a closer understanding of the demands and monitor how the funds were being used. In March 2002, inspection teams from the Ministry of Civil Affairs were sent to provinces to check on the figures for the number of people eligible for assistance but who failed to receive assistance, the financial commitment from local governments and the information management system of the programme. The national audit indicated that the programme covered a total of 13.9 million recipients with 5.4 million people being expected to receive assistance soon. Among the beneficiaries, 49.5 per cent were without jobs, 9.8 per cent had insufficient incomes, 30.2 per cent were their family members, 4.8 per cent were retirees and 5.7 per cent belonged to the traditional 'three nos' (Yang, 2002). As such, this programme serves mainly people facing inadequate income protection due to unemployment, low wages and old age. These people are considered the ‘new urban poor’ (Guan, 2003; Hussain, 2003). Different from the 'old urban poor', the majority of the 'new urban poor' are able to work. A study of the recipient profile in five major cities by the Chinese Academy of Social Sciences in 2003 found that 53 per cent 
were unemployed persons, 9 per cent were employed, 26 per cent were children and 12 per cent were older people, chronically sick or disabled (Tang, 2004).

To further understand the background of the recipients and the operations of the programmes, the Ministry of Civil Affairs embarked on a sample survey of 10,000 recipient households, receiving 6,505 returned questionnaires in September 2002. The study sought information on the profile of the recipients, how and when they received their benefits, and perceived difficulties encountered (Ministry of Civil Affairs, 2003). The findings showed that 56 per cent of the households had two or three persons. About 34 per cent of them had disabled persons, and 64.9 per cent had chronically sick members in their family. Some 62 per cent of the respondents had monthly MLSGS benefits of less than 100 yuan and 30 per cent per cent between 101 and 200 yuan. In terms of payment arrangements, 60 per cent of them received their payments monthly, 29 per cent quarterly and 3 per cent half-yearly. Some 90 per cent of them received payments promptly and 91 per cent of them received their full payment. They received their payments mainly through the street offices. Most of them regarded job-seeking, medical care and education expenses as the major difficulties they encountered.

The survey indicated that the delivery of the programme involved some inconsistencies in terms of prompt and full payment of benefits and that the benefits received were low. Similar to many other places, poverty in China is often associated with disabilities and poor health (Chen, Lucas \& Gong, 2004). Besides financial and medical care assistance, they need employment support. More importantly, there is a lack of a comprehensive and unified data set at the national level on the overall profile of the recipients, including their age and sex distribution, family structure, duration of receiving the benefits and problems encountered.

\section{An appraisal}


Given the phenomenal increases in the number of recipients in 2002 and 2003, the essential question is whether the number will continue to increase. The monthly figures in 2004 showed that the number had increased to a peak of 22.6 million recipients in the first quarter, and then declined gradually to around 22 million in the last quarter (Ministry of Civil Affairs, 2004a). Despite its widened coverage, the scheme still excludes those without local urban household registration status, notably migrant workers. It is estimated that there are around 100 million rural migrants working in cities, and they oftentimes face the common plight of failing to receive their wages promptly (Mo, 2004; Solinger, 1999). Given the Chinese government’s intention to eventually abolish the household registration system, rural migrants with a stable job and source of income as well as a permanent address should be granted residential status (Zhou, 2004). When more rural migrants have residential status, it will be more difficult to exclude them from the programme.

Operationally, the programme has relied too much on the community administrative structure to deliver the services. This has the advantage that it can keep administrative costs low and operations flexible. Yet under a decentralised administrative and delivery system with loose operational guidelines, individual neighbourhood cadres vary greatly in how they interpret and apply the guidelines. As popularly elected residents' representatives, neighbourhood cadres are not professionally trained to administer the programme. There is a lack of systematic and standardised procedures to handle investigations and to make arrangements for job referrals, training and voluntary community work. The programme system also does not incorporate an effective system of appeal. The whole application and review process may be affected by the personal relationships between the neighbourhood cadres and the applicants or recipients. To be sure, the process of publicising the names of the applicants, involving neighbours in the investigation process and using informal mechanisms, such as checking on life styles and consumption patterns to determine eligibility is subject to corruption and manipulation. 
Furthermore, ‘voluntary’ community work for recipients, such as garbage collection and street cleaning, is carried out within the neighbourhood where they live. Again, this is a very stigmatising practice that needs to be reviewed.

Besides programme administration, the effectiveness of the social assistance programme is largely dependent on the coordination between different benefits, notably employment, housing, medical care and education services. Since the majority of the recipients are able-bodied and have the ability to work, the priority of the social assistance programme should be to facilitate and motivate their re-employment and re-entry into the labour market. The Civil Affairs Departments in charge of the policy and operation of the programme as well as the community-based delivery system do not specialise in job creation, training and referrals. The effectiveness of the current system in handling re-employment is in doubt (Ge, 2004). As in many other welfare states, the core concern of the Chinese social assistance programme is how to avoid welfare dependency and design a more effective employment-oriented, activation or ‘workfare’ approach to social assistance (OECD, 2005). The availability of medical and educational support is of paramount importance to alleviate the plight of the poor. Currently, these benefits are only established in a limited way in large cities.

Even though the number of recipients has stabilised, the expenditures will continue to soar. Improvements in the basic assistance level and other supplementary benefits will further burden the local governments. The crux of the problem is how to ensure those financially less developed provinces have the sufficient resources to support the programme. Most likely, the central government will have to shoulder the staggering responsibility of financing this programme.

The over-reliance on the government to tackle poverty is largely due to the under-development of non-governmental organisations in China. By 2003, there were around 1,200 charity foundations in China engaging in the field of poverty alleviation, education and 
environmental protection. They have rather limited total assets of five billion yuan (China Daily, 20 March 2004). A survey of non-governmental organisations in China showed that their development is hindered by a lack of a public donation culture, dominating control from the government and weak leadership (Deng, 2001).

A study carried out in Hubei province in 2002 revealed that most of the urban residents accepted that it was an obligation of the government to help the poor. But only 66 per cent of the people had heard about the MLSGS. Some 26 per cent of the recipients perceived MLSGS benefits as shameful. Only 23 per cent would not agree to have their names made public by the government. In the event of disputes over the MLSGS benefits, some 70 per cent of the recipients would appeal to their work unit administrators for assistance (Lin, Chang \& Yan, 2004).

As a core social security programme, it provides nationwide basic protection to poverty-stricken urban residents. It is to be hoped that the programme will be extended to include migrant workers and villagers. To be effective, the programme has to be supplemented by other social assistance benefits, notably in housing, employment, medical care and education. The decentralised delivery system has to be reviewed to improve the standardisation of assistance levels and eligibility criteria. Facing the conflict of roles as elected residents' representatives and programme staff, non-professionally trained neighbourhood cadres are not suitable to administer the programme. The need to respect and protect the privacy rights of recipients should be considered. Financial support, particularly for poorly developed cities, should be ensured through clearly defined roles and responsibilities for the central and local governments. To improve the policy and the programme, the data management system must first be improved, and more research must be conducted on the needs of the recipients and the effectiveness of the programme in poverty alleviation. 


\section{Conclusion}

In summary, the emerging social assistance programme in China is administratively decentralised and community-based. Even though it is designed as a right-based programme, local and neighbourhood governments have substantial discretion to determine eligibility and entitlements. The programme caters to a mixed group of low-income people, including the unemployed, older people, the sick and the disabled. All benefits are means-tested, stringent, low level and heavily stigmatised. Complementary support in housing, medical care, education, employment and personal social services is largely under-developed, inadequate and not institutionalised. The role of private charity is extremely limited. With these features, Chinese social assistance does not seem to fit neatly into any one of the typologies of social assistance regimes categorised by Gough et al. (1997). Accordingly, it is still premature to group the Chinese social welfare system conceptually together with those of other countries (White, 1998).

Urban poverty has been aggravated by the rising layoffs and costs of social services, including medical care, education and housing. In addition, the emergence of the social assistance programme in China was triggered by the increasing inability of the employment-based social security system to meet the challenges of persistent unemployment and an ageing population. With the declining importance of employment-based welfare, local governments are expected to gradually take on the responsibility. Yet a welfare system financed by local government needs time to evolve. Now the top priority of development has shifted away from the 'universal' social insurance programmes towards the establishment and consolidation of the residual social assistance system in the cities.

Overall, social welfare reform is more guided by pragmatic concerns than by a clear visionary direction and a comprehensive developmental blueprint. Reforms are incremental and piecemeal, rather than employing a 'shock therapy' approach based on introducing radical 
changes. Assuming the role of macro-control at the top, the central government delineates broad guiding principles for reforms. These reforms are indicative rather than mandatory and universal. At the local level, governments are encouraged to experiment with different solutions and models according to local circumstances and financial capacity. Meanwhile, policy adjustments are made based on learning from research studies and advices from international organisations and consultants. After some years of continuous experimentation and evaluation, the government, often through legislation, is attempting to unify diversified practices by promoting one of the more successful models. The strength of this approach is that it can minimise resistance and facilitate readjustments through feedbacks from programme implementation. The shortcoming is that regional disparities in social welfare development are substantial. Given the decentralised and segmented social welfare system, access and entitlement to social services and social security benefits is primarily differentiated among occupational groups, economic sectors and geographical regions. In effect, an underclass of the 'new poor' made up of the unemployed, rural migrants, and the sick and disabled has emerged in the cities.

In the absence of a compensatory social and economic policy, both market-oriented economic and social insurance reforms have inevitably exacerbated the tendency towards inequality in the distribution of income. In 2000, the Gini coefficient reached 0.397 (Khan \& Riskin, 2001: 7). Growing income disparities threaten social stability (Perry \& Sheldon, 2000). The threat of social unrest is imminent given mounting corruption, unemployment, poverty and income disparity.

In the end, the MLSGS, a residual and means-tested social security programme, has emerged as an integral part of the social protection system, filling the gaps created by the reforms in the social insurance programmes. It has performed the vital role of facilitating economic reforms and maintaining social stability through offering protection to the 
unemployed and laid-off employees. The development of this social assistance programme also reflects the need to reform the largely inefficient and ineffective housing and medical care programmes for the low-income population. On the other hand, in order to build a coherent social welfare system for China, there is an urgent need to review the country's overall social protection system.

\section{References}

Asian Development Bank (May 2004). Poverty profile of the People's Republic of China. <http://www.adb.org/documents/reports/poverty_profile_PRC/PRC.pdf>

Beijing Labour and Social Security Bureau (2004). Beijing social security benefit standards over the years. <http//:www.bjld.gov.cn/tszl/zdshbz/t20031225_8648.htm>

Bloom G, Tang S, eds. (2004). Health Care Transition in Urban China Aldershot, Hants, Ashgate.

Braithwaite J, Grootaert C, Milanović B (2000). Poverty and Social Assistance in Transition Countries. New York, St. Martin's Press.

Chen JY, Lucas H, Gong YL (2004). Urban health reform in China: the impact on vulnerable groups. In: Bloom G, Tang S, eds. Health Care Transition in Urban China. Aldershot, Hants, Ashgate, pp. 96-110.

China Daily (23 December 2003). Employment situation still serious. <http://www.china.org.cn/english/2003/Dec/83108.htm>

China Daily (20 March 2004). China issues new rules on public welfare foundations. <http://www.china.org.cn/english/2004/Mar/90903.htm>

China Daily (21 December 2004). Re-employment services to be phased out. $<$ http://www.china.org.cn/english/2004/Dec/115518.htm>

China Daily (17 January 2005). Chinese pay more for medical services. $<$ http://service.china.org.cn/link/wcm.Show_Text?info_id=118067\&p_qry=medical\%20an d\%20care>

China Internet Information Centre (2004). China: facts and figures. < $\underline{\text { http://china.org.cn/english/en-shuzi2004/index.htm> }}$

China Internet Information Centre (2005). Repayment of the 33.1 billion yuan of the wages of migrant workers, achieving the objective of the first stage. 8 January. 
http://www.china.org.cn/chinese/zhuanti/nmg/750931

China Network (2005). State Council Development Research Centre's assessment and recommendations on medical care reform. 27 July.

http://www.china.com.cn/chinese/health/927874.htm

China Research Centre on Aging (2002). Data Analysis of the Sampled Survey on the Aging Population in China. Beijing, China Standard.

Deng GS (2001). Non-profit Organisation Evaluation. Beijing, Social Sciences.

Ditch J (1999). Full circle: a second coming for social assistance. In: Clasen J, ed. Comparative Social Policy: Concepts, Theories, and Methods. Oxford, Blackwell, pp. 114-35.

Ditch J, Bradshaw J, Clasen J, Huby M, Moodie M (1997). Comparative Social Assistance: Localisation and Discretion. Aldershot, Hants, Ashgate.

Ditch J, Oldfields N (1999). Social assistance: recent trends and themes. Journal of European Social Policy 9(1): 65-76.

Eardley T Bradshaw J, Ditch J, Gough I, Whiteford P (1996a). Social Assistance in OECD Countries (Volume I): Synthesis Report. London, HMSO.

Eardley T, Bradshaw J, Ditch J, Gough I, Whiteford P (1996b). Social Assistance in OECD Countries (Volume II): Country Report. London, HMSO.

Ge DS (2004). Establishing community public service organisation to promote the management and re-employment of MLSG recipients. Research Paper, Ministry of Civil Affairs. <http://www.mca.gov.cn/artical/content/200482410582/20041215153433.html>

Gough I, Bradshaw J, Ditch J, Eardley T, Whiteford P (1997). Social assistance in OECD countries. Journal of European Social Policy 7(1): 17-43.

Guan XP (2003). Poverty and anti-poverty policies in urban China. In: Tang K, Wong CK, eds. Poverty Monitoring and Alleviation in East Asia. New York, Nova Science, pp. 15-37. Guangzhou People’s Government (2004). Information on the application of the Minimum Living Standard Guarantee System. <www.gz-gov.org/index.htm>

Hong DY, Wang H (2001). The progress of the reform of the Minimum Living Standard Guarantee System for urban residents. In: Ru X, Lu XY, Li PL, eds. 2002: China’s Social Situation Analysis and Prediction. Beijing, Social Sciences Documentation, pp. 105-12. Hussain A (2003). Urban poverty in China: measurement, patterns and policies. Policy Discussion Paper. Geneva, International Labour Office, January. $<$ http://www.ilo.org/public/english/protection/ses/index.htm>

Hutton S, Redmond G, eds. (2000). Poverty and Transition Economies. London, Routledge. Information Office, State Council of the PRC (2002). Government white paper - labour and 
social security in China. April <http//www.china.org.cn/e-white/20020429/index.htm> Information Office, State Council of the PRC (2004). Government white paper - China's employment situation and policies. April.

<http://www.china.org.cn/e-white/20040426/index.htm>

Information Office, State Council of the PRC (2004). Government white paper - China's social security and its policy. September. <http://www.china.org.cn/e-white/20040907/index.htm> Ji JS (2002). Study on the problem and policy of implementing the Minimum Living Standard Guarantee System. Economic Sector 6: 28-31.

Khan AR, Riskin C (2001). Inequality and Poverty in China in the Age of Globalisation, Oxford, Oxford University Press.

Leung J (1994). Dismantling the iron rice bowl: welfare reforms in the PRC. Journal of Social Policy 23(3): 341-61.

Leung J (2000). Community building in China: from welfare to politics’. Community Development Journal 45(4): 425-27.

Leung J (2003). 'Social security reforms in China: issues and prospects. International Journal of Social Welfare 12(2): 73-85.

Leung J, Nann R (1995). Authority and Benevolence: Social Welfare in China. Hong Kong, Chinese University of Hong Kong.

Leung J, Wong H (1999). The emergence of a community-based social assistance programme in urban China. Social Policy \& Administration 33(1): 39-54.

Li YC (2004). Poverty and Social Assistance Study. Beijing, Peking University Press.

Lin LH, Chang XY, C. Yan CY (2004). An understanding of the awareness on the situation of rights by urban residents in Hubei province through the implementation of the MLSGS. Hubei Social Sciences 1: 32-35.

Lustig N, Inter-American Development Bank, eds. (2001). Shielding the Poor: Social Protection in the Developing World. Washington, DC, Brookings Institute Press.

MacKay R (2001). Social protection through social assistance. In: Hoskins DD, Dobbernack D, Kuptsch C, eds. Social Security at the Dawn of $21^{\text {st }}$ Century: Topical Issues and New Approaches. New Brunswick, NJ, Transaction, pp. 301-33.

Mikhalev V (2001). Poverty and social assistance. In: Klein LR, Pomer MI, eds. The New Russia: Transition Gone Awry. Stanford, CA, Stanford University Press, pp. 251-68. Milanović B (1998). Income, Inequality, and Poverty during the Transition from Planned to Market Economy. Washington, DC, World Bank. 
Ministry of Civil Affairs (1999). Regulations on the Urban Minimum Living Standard Guarantee System.

< http://www.mca.gov.cn/artical/content/WJYL_ZDSHBZ/20049193140.html>.

Ministry of Civil Affairs (2003). Announcement by the Ministry of Civil Affairs on the results of the national survey on 10,000 MLSGS recipient households.

$<$ http://www.mca.gov.cn/callboard/index.asp?page=5\&sortcode=public $>$

Ministry of Civil Affairs (2004a). Minimum Living Standard Guarantee System - statistics. $<$ http://www.mca.gov.cn/artical/index.asp?currentid=55\&parentid=9 $>$

Ministry of Civil Affairs (2004b). 2003-2004 report on the development of the work of civil affairs in China. <http://www.china.org.cn/chinese/zhuanti/minzheng04/589736.htm>

Ministry of Labour and Social Security (2004). The situation of labour and social security work. $<$ http://www.molss.gov.cn/news/2004/0309b.htm>

Mo Y (2004). 2003-2004: China’s Employment Report. Beijing, China Labour Social Security. <http://www/china.org.cn/Chinese/zhuanti/0304jybg/739970.htm>

Organisation for Economic Co-operation and Development (OECD) (1998a). The Battle Against Exclusion: Social Assistance in Australia, Finland, Sweden and the United Kingdom. Paris, OECD.

Organisation for Economic Co-operation and Development (OECD) (1998b). The Battle Against Exclusion: Social Assistance in Belgium, the Czech Republic, the Netherlands and Norway. Paris, OECD.

Organisation for Economic Co-operation and Development (OECD) (1999). The Battle Against Exclusion, Social Assistance in Canada and Switzerland. Paris, OECD.

Organisation for Economic Co-operation and Development (2005). Extending Opportunities, How Active Social Policy Can Benefit Us All. Paris, OECD.

Oritz I (2000). Social protection and the Asian Development Bank. In: Asian Development Bank, the World Bank, eds. The New Social Policy Agenda in Asia: Proceeding of the Mania Social Forum. Manila, Asian Development Bank, pp. 95-98.

Oritz I (2002). Reforming social protection systems in Asia and the Pacific: a perspective from the Asian Development Bank. In: OECD, ed. Towards Asia’s Sustainable Development: The Role of Social Protection. Paris, OECD, pp. 263-96.

People's Daily (26 May 2004). Premier Wen reiterates commitment on global poverty reduction. $<$ http//:www.china.org.cn/English/government/96507.htm>

Perry E, Sheldon M, eds. (2000). Chinese Society: Change, Conflict, and Resistance. New York, Routledge. 
Ru X, Lu XY, Li PL, eds. (2003). Analysis and Forecast on China’s Social Development 2004. Beijing, Social Sciences Documentation.

Sainsbury D (1996). Gender, Equality and Welfare States. Cambridge, Cambridge University Press.

Saraceno C, ed. (2002). Social Assistance Dynamics in Europe: National and Local Poverty Regimes. Bristol, The Policy Press.

Shanghai Civil Affairs Bureau (2004a). Shanghai civil affairs social assistance Situation. <http://www.shmzj.gov.cn/node2/node396/node405/node496/node497/userobject1ai2790.h tml>

Shanghai Civil Affairs Bureau (2004b). Civil affairs new concepts. $<$ http//:www.shmzj.gov.cn/node2/node574/userobject1ai3034.html>

Sin Y (2005). Pension liabilities and reform options for old age insurance. Working Paper Series on China, Paper No. 2005-1, Washington DC, The World Bank. $<$ http://siteresources.worldbank.org/intpensions/resources/pensions/chinapensionliabilities. pdf $>$

Solinger D (1999). Contesting Citizenship in Urban China. San Francisco, University of California Press.

Subbarao K, Bonnerjee A, Jeanine B, Carvalho S, Ezemenari K, Graham C, Thompson A (1997). Safety Net Programs and Poverty Reduction: Lessons from Cross-country Experience. Washington, DC, World Bank.

Tang J (2004). The situation and prospects of the MLSGS. In: Ru X, Lu XY, Li PL, eds. 2005: China's Social Situation Analysis and Prediction. Beijing, Social Sciences Documentation, pp. 248-59.

Tang J, Sha L, Ren XZ (2003). Report on Poverty and Anti-poverty in Urban China. Beijing, Huaxia.

The Economist (20 march 2004). Behind the mask: a survey of business in China.

Walder A (1986). Communist Neo-traditionalism: Work and Authority in China's Industry. Berkeley, University of California Press.

White G (1998). Social security reforms in China: towards an East Asian model? In: Goodman R, White G, Kwon HJ, eds. The East Asian Welfare Model: Welfare Orientalism and the State. London, Routledge, pp. 175-98.

Wilson F, Kanji N, Braathen E, eds. (2001). Poverty Reduction: What Role for the State in Today's Globalized Economy? Capetown, Zed Books.

World Bank (2004). China: overcoming rural poverty. 
<http://poverty.worldbank.org/library/view/8077>

Yang YY (2002). Strengthening leadership, regulating service management - promoting the standard of MLSGS. China Civil Affairs 11: 12-13.

Yu XX (2002). Poverty alleviation through Minimum Living Standard Guarantee System: the background of expanding the coverage. China Society May: 10-13.

Zheng HS (2003). China's Social Development Study Report 2002 - Vulnerable Populations and Social Support. Beijing, China People’s University Press.

Zhou XC (2004). Reviewing the reform of civil affairs from the perspective of household registration reform. Research Paper, Ministry of Civil Affairs.

<http://www.mca.gov.cn/news/content/search/2004134703.html> 
Table 1. Number of MLSGS recipients and expenditures over the years.

\begin{tabular}{|l|l|l|l|}
\hline Year & $\begin{array}{l}\text { Total number of } \\
\text { recipients in millions of } \\
\text { people (\% increase over } \\
\text { previous year) }\end{array}$ & $\begin{array}{l}\text { Total expenditures in } \\
\text { billion yuan }\end{array}$ & $\begin{array}{l}\text { Contribution from } \\
\text { central government in } \\
\text { billion yuan (\%) }\end{array}$ \\
\hline 1997 & 2.00 & 1.15 & \\
\hline 1998 & $2.34(17 \%)$ & 1.20 & $0.8(27 \%)$ \\
\hline 1999 & $2.66(13.7 \%)$ & 1.54 & $2.3(42.4 \%)$ \\
\hline 2000 & $4.03(51.5 \%)$ & 2.96 & $4.6(42.4 \%)$ \\
\hline 2001 & $11.70(190.3 \%)$ & 5.42 & $9.2(60.9 \%)$ \\
\hline 2002 & $20.65(76.5 \%)$ & 10.86 & \\
\hline 2003 & $22.47(8.8 \%)$ & 15.10 & \\
\hline
\end{tabular}

Source: Ministry of Civil Affairs (2005ab). 